
\title{
AdindaMas
}

Volume 1 Nomor 2, Januari 2022

DOI: https://doi.org/10.37726/adindamas.v1i2.325

\section{Sosialisasi Penggunaan Marketplace Tokopurwakarta.Com Kepada UMKM Di Desa Benteng Kecamatan Campaka Kab. Purwakarta}

\author{
Agung Tripramudi ${ }^{1}$, Jalaludin ${ }^{2}$, Moch. Cahyo Sucipto ${ }^{3}$, Toni Arif Fauzi ${ }^{4}$ \\ 1,2,3Sekolah Tinggi Iilmu Ekonomi Syariah (STIES) Indonesia Purwakarta \\ 1agungtripramudi088@gmail.com \\ 2Jalaludinstiesip@gmail.com \\ 3Moch.cahyosucipto@sties-purwakarta.ac.id \\ ${ }^{4}$ Mahasiswa Sekolah Tinggi Iilmu Ekonomi Syariah (STIES) Indonesia Purwakarta \\ ${ }^{4}$ toniariffauzi@gmail.com
}

\begin{abstract}
ABSTRAK
Berdasarkan hasil observasi penjualan para UMKM dan masyarakat di Desa Benteng belum optimal, harapan warga dengan adanya pengenalan aplikasi atau marketplace akan mampu meningkatkan jumlah penjualan sehingga berdampak pada bertambahnya keuntungan yang diperoleh dari penjualan. Saat ini warga masih belum memiliki pengetahuan tentang marketplace Tokopurwakarta.com atau Topur yang bisa digunakan sebagai sarana pendukung promosi penjualan secara online. Melalui program pengabdian kepada masyarakat ini tim PKM membantu warga memberikan edukasi dan informasi yang diperlukan sampai dengan membantu proses pembuatan akun marketplace untuk warga. Tujuan dari program pengabdian kepada masyarakat ini adalah untuk sosialisasi penggunaan marketplace tokopurwakarta.com kepada UMKM di desa Benteng Kecamatan Campaka Kab. Purwakarta. Kegiatan Pengabdian kepada Masyarakat yang telah dilaksanakan ini dapat diambil kesimpulan bahwa proses sosialisasi penggunaan marketplace tokopurwakarta.com mulai dari awal hingga tahap akhir dibuktikan dengan bertambahnya kepercayaan para pelaku UMKM dalam memasarkan produk
\end{abstract}


jualannya, dan bagi masyarakat menambah pengetahuan tentang transaksi secara online pada marketplace tokopurwakarta.com.

Kata kunci - Sosialisasi, Penggunaan Marketplace, Tokopurwakarta.Com, UMKM.

\section{ABSTRACT}

Based on the observation that sales of MSMEs and the community in Benteng Village have not been optimal, residents hope that with the introduction of an application or marketplace, it will be able to increase the number of sales so that it has an impact on increasing the profits obtained from sales. Currently, residents still do not have knowledge about the Tokopurwakarta.com or Topur marketplace which can be used as a means of supporting online sales promotions. Through this community service program, the PKM team helps residents provide the necessary education and information to assist in the process of creating marketplace accounts for residents. The purpose of this community service program is to socialize the use of the tokopurwakarta.com marketplace to MSMEs in Benteng Village, Campaka District, Kab. Purwakarta. This Community Service activity that has been carried out can be concluded that the process of socializing the use of the tokopurwakarta.com marketplace from the beginning to the final stage is evidenced by the increased trust of MSME actors in marketing their selling products, and for the public to increase knowledge about online transactions on the tokopurwakarta marketplace. com.

Keywords - Socialization, Use of Marketplace, Tokopurwakarta.Com, MSMEs.

\section{PENDAHULUAN}

Desa Benteng merupakan salah satu desa yang ada di kecamatan Campaka kabupaten Purwakarta, Desa Benteng mempunyai sektor industri dengan adanya pabrik PT. EASTWEST SEED Cap Panah Merah yang memproduksi Benih Palawija dan hortikultura yang bermutu tinggi untuk diekspor dan untuk kebutuhan dalam negeri,sebagai produk unggulan Agro Industri Kabupaten Purwakarta. Kemudian di desa Benteng juga terdapat Instalasi Biogas yang dihasilkan dari kotoran sapi hasil kerja sama melalui CSR dari PT. Hino Indonesia Manufacture dengan fasilitator Badan Lingkungan Hidup Kabupaten Purwakarta bekerjasama dengan Kelompok Peternak Sapi di Desa Benteng. Selain itu, masyarakat di desa Benteng banyak juga yang memiliki usaha sendiri mulai warungan sampai Home Industry. Cara memasarkan produknya pun masih menggunakan metode konvensional yaitu dengan membuat daftar menu dalam spanduk, memasarkan menu masakan melalui platform whatsapp, membuat poster sederhana, dan melalui informasi dari mulut ke mulut.

E-commerce pertama di purwakarta telah didirikan oleh Salman Al Farisi yang merupakan salah satu pengusaha muda asal Kabupaten Purwakarta, berhasil membuat sebuah aplikasi jual beli berbasis jaringan (e-commerce) yaitu Tokopurwakarta.com atau Topur. Aplikasi ini dibuat bertujuan untuk membantu

ADINDAMAS (Jurnal Pengabdian Kepada Masyarakat), Volume 1, Nomor 2, Januari 2022 http://journal.sties-purwakarta.ac.id/index.php/adindamas/ ISSN: 2798-2874 (Media Online) 2798-4702 (Media Cetak) 
serta memberikan wadah kepada pelaku usaha mikro kecil dan menengah (UMKM) yang berada diwilayahnya. Salman mulai belajar berwiraswasta sejak masih duduk di bangku SMPN 2 Purwakarta. Ia mengakui perihatin dengan kondisi perkembangan UMKM di Purwakarta yang sebagian besar masih kesulitan pemasaran produk milik mereka. Atas dasar itu kemudian saya membuat aplikasi jual-beli berbasis jaringan (e-commerce) bernama Tokopurwakarta.com atau Topur.

Aplikasi Topur akan memudahkan pelaku UMKM dalam memperluas akses pasar kepada konsumen. Sehingga produk yang dijual akan lebih mudah diketahui oleh masyarakat luas. Pedagang yang bergabung akan diberikan edukasi terkait tata kelola keuangan yang baik hingga aturan pemerintah yang harus diikuti UMKM. Banyak UMKM yang pada akhirnya cari pendanaan untuk membayar utang bukan untuk pengembangan usaha, bahkan banyak juga yang belum terdaftar atau berizin resmi sehingga tidak membayar pajak karena tidak mengetahui regulasi.perbedaan aplikasi Topur dengan e-commerce lain yaitu pada sistemnya berbasis syariah. tidak pakai istilah 'bakar uang'. Topur lebih berorientasi pada profit, bukan branding dan penampungan data base pelanggan.

Salman memastikan seluruh pedagang yang berjualan di e-commerce tersebut adalah pedagang asli karena melalui proses pendaftaran secara tatap muka. Sejak diperkenalkan pada pertengahan Desember 2019 lalu, jumlah pedagang yang bergabung sudah mencapai 130 dari bidang fesyen, kuliner, perlengkapan kantor hingga elektronik.

Berdasarkan hasil analisa dan wawancara yang dilakukan oleh tim Pengabdian Kepada Masyarakat, diperoleh informasi bahwa saat ini hasil penjualan para pedagang/ masyarakat di Desa Benteng belum optimal. Harapan warga dengan adanya pengenalan aplikasi atau marketplace akan mampu meningkatkan jumlah penjualan sehingga berdampak pada bertambahnya keuntungan yang diperoleh dari penjualan. Saat ini warga masih belum memiliki pengetahuan tentang marketplace Tokopurwakarta.com atau Topur yang bisa digunakan sebagai sarana pendukung promosi penjualan secara online. Sosialisasi marketplace Tokopurwakarta.com tersebut merupakan hal yang baru bagi warga desa Benteng Kac. Campaka. Melalui program pengabdian kepada masyarakat ini tim PKM membantu warga memberikan edukasi dan informasi yang diperlukan sampai dengan membantu proses pembuatan akun marketplace untuk warga. Tujuan dari program pengabdian kepada masyarakat ini adalah untuk sosialisasi penggunaan marketplace tokopurwakarta.com kepada UMKM di desa Benteng Kecamatan Campaka Kab. Purwakarta. 


\section{A. Tempat dan Waktu}

\section{METODE}

Kegiatan pengabdian kepada masyarakat tentang Sosialisasi Penggunaan Marketplace Tokopurwakarta.Com Kepada UMKM Di Desa Benteng Kecamatan Campaka Kab. Purwakarta dilaksanakan pada tanggal 11-24 Februari 2019.

\section{B. Ruang Lingkup dan Objek Pengabdian}

Objek yang menjadi sasaran dari kegiatan pengabdian kepada masyarakat ini adalah para pelaku UMKM di Desa Benteng Kecamatan Campaka Kab. Purwakarta.

\section{Pendekatan atau teknik pengabdian}

Tahapan kegiatan yang dilakukan oleh tim PKM dalam program kegiatan pengabdian masyarakat di Desa Benteng Kecamatan Campaka Kab. Purwakarta adalah sebagai berikut:

a. Pembekalan dan penentuan tujuan lokasi program pengabdian masyarakat Lokasi program pengabdian kepada masyarakat berlokasi Desa Benteng Kecamatan Campaka Kab. Purwakarta. Berikut gambar lokasi daerah yang diambil dari google map:

\section{Gambar 2.1}

Lokasi PKM Desa Benteng Kec. Campaka Purwakarta

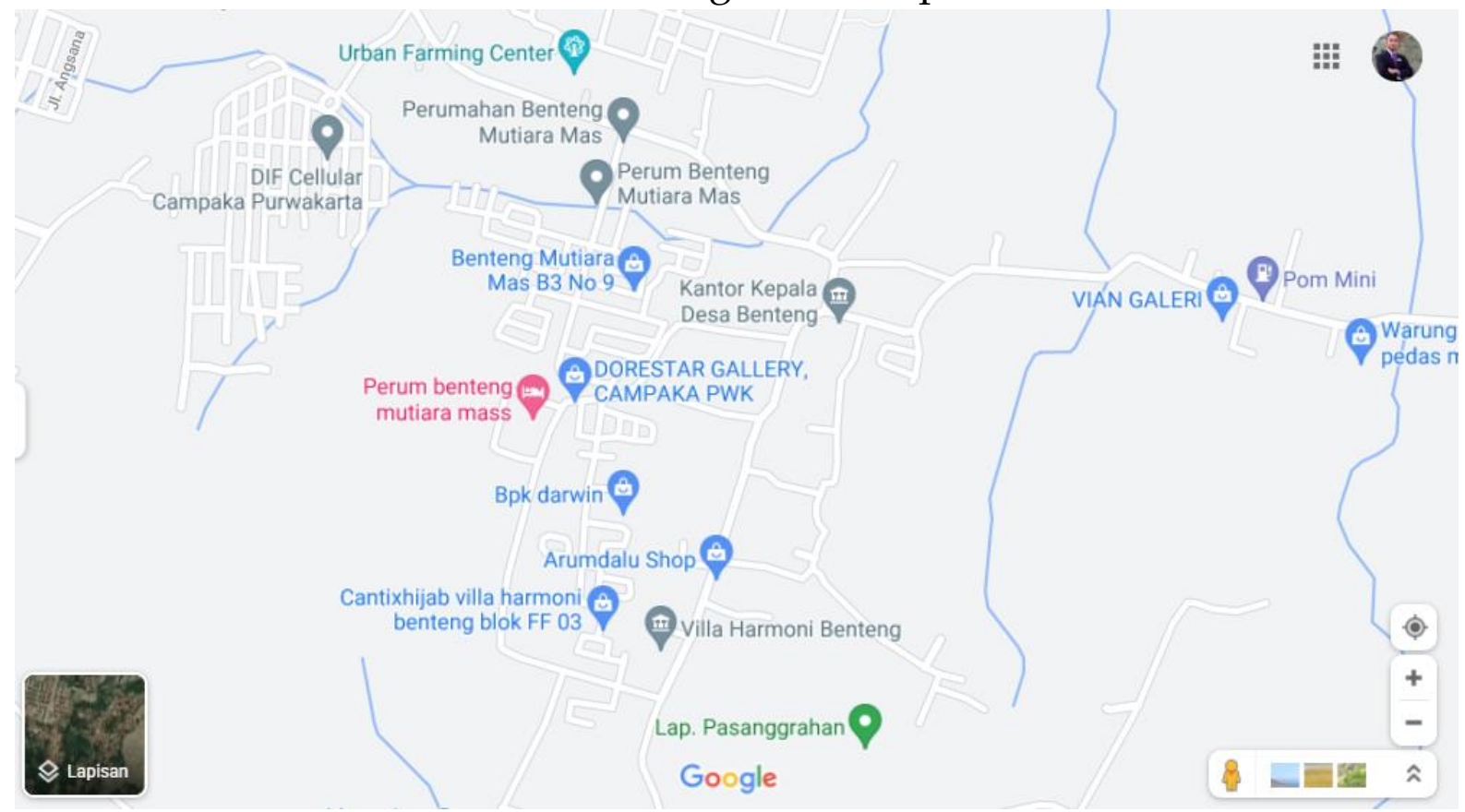

b. Melakukan Survei Lokasi Kegiatan Program Pengabdian Masyarakat Survei lokasi dan kunjungan dilakukan oleh perwakilan tim PKM. Kunjungan ini bertujuan untuk bersilaturahmi dengan perwakilan warga serta melakukan 
wawancara dan mencari informasi tentang situasi dan kondisi lingkungan sekitar pelaksanaan program Pengabdian Kepada Masyarakat.

c. Melakukan Analisa Sosial

Sepanjang Analisa sosial dilakukan di Desa Benteng Kecamatan Campaka Kab. Purwakarta, analisa sosial dilakukan agar tim PKM mengetahui tentang keadaan geografis, kedaan lingkungan, kondisi sosial dan ekonomi, kegiatan masyarakat serta permasalahan yang di hadapi oleh warga Desa Benteng Kecamatan Campaka Kab. Purwakarta. Sambil melakukan koordinasi lebih lanjut untuk perencanaan program kerja yang akan dilaksanakan.

d. Tahap Pelaksanaan Program Kerja

Pengabdian Masyarakat Tahap pertama, yaitu dengan melakukan kunjungan ke rumah warga untuk mendata pelaku UMKM dan varian produk yang akan dipromosikan di Marketplace Tokopurwakarta.Com. Tahap kedua, melakukan wawancara dengan beberapa pelaku UMKM mengenai kesulitan penjualan yang di hadapi.

e. Proses Realisasi Program Kerja Pengabdian Masyarakat

Realisasi kegiatan program pengabdian kepada masyarakat berupa pengenalan penggunaan Marketplace Tokopurwakarta.Com dilakukan dengan sistem seminar dan Focus Discussion Group. Proses Sosialisasi Penggunaan Marketplace Tokopurwakarta.Com dimulai dengan proses download dan instal aplikasi marketplace ke smartphone Pemillik UMKM, kemudian proses pendaftaran dan pembuatan akun sesuai dengan data diri pemilik akun yang akan di daftarkan. Langkah selanjutnya adalah memandu pemilik UMKM melengkapi data dan syarat pembuatan akun. Proses pembuatan akun selesai sampai dengan akun tersebut telah terverifikasi dan siap digunakan. Tahap berikutnya adalah memberikan informasi dan edukasi kepada warga pengguna akun tersebut bagaimana cara mengoperasikan dan manfaat yang diperoleh dengan adanya akun tersebut.

\section{HASIL DAN PEMBAHASAN}

Program kerja Pengabdian kepada Masyarakat bertujuan untuk sosialisasi penggunaan marketplace tokopurwakarta.com kepada UMKM di desa Benteng Kecamatan Campaka Kab. Purwakarta, kegiatan ini juga membantu pelaku UMKM mengelola dan memasarkan produk usaha guna menunjang dan memenuhi kebutuhan ekonomi harian. Pelaku UMKM di desa Benteng saat ini memasarkan dan mempromosikan produk usaha masih menggunakan cara konvensional. Melalui program pengabdian kepada masyarakat ini tim PKM memberikan edukasi dan informasi yang bermanfaat bagi para pelaku UMKM dan masyarakat terkait penggunaan marketplace tokopurwakarta.com. Penjualan dan pemasaran dengan cara konvensional dipandang belum memberikan hasil yang memuaskan. Melalui metode sosialisasi marketplace tokopurwakarta.com ini diharapkan penjualan dan

ADINDAMAS (Jurnal Pengabdian Kepada Masyarakat), Volume 1, Nomor 2, Januari 2022 http://journal.sties-purwakarta.ac.id/index.php/adindamas/ ISSN: 2798-2874 (Media Online) 2798-4702 (Media Cetak) 
pemasaran pelaku UMKM dapat meningkatkan jumlah penjualan serta mampu memberikan keuntungan yang lebih besar. Hal ini disebabkan karena dengan adanya marketplace tokopurwakarta.com kemungkinan akan dapat menambah jumlah pelanggan dan memperluas area operasional pesanan.

Proses sosialisasi marketplace tokopurwakarta.com dilakukan di beberapa tempat dan dilakukan kunjungan secara door to door ke rumah pelaku UMKM desa Benteng untuk wawancara dengan pelaku UMKM mengenai kondisi serta permasalahan yang di hadapi dalam mempromosikan usaha kuliner.

\section{Gambar 3.1}

Sosialisasi Penggunaan Marketplace Tokopurwakarta.Com kepada UMKM di desa Benteng Kecamatan Campaka Kab. Purwakarta

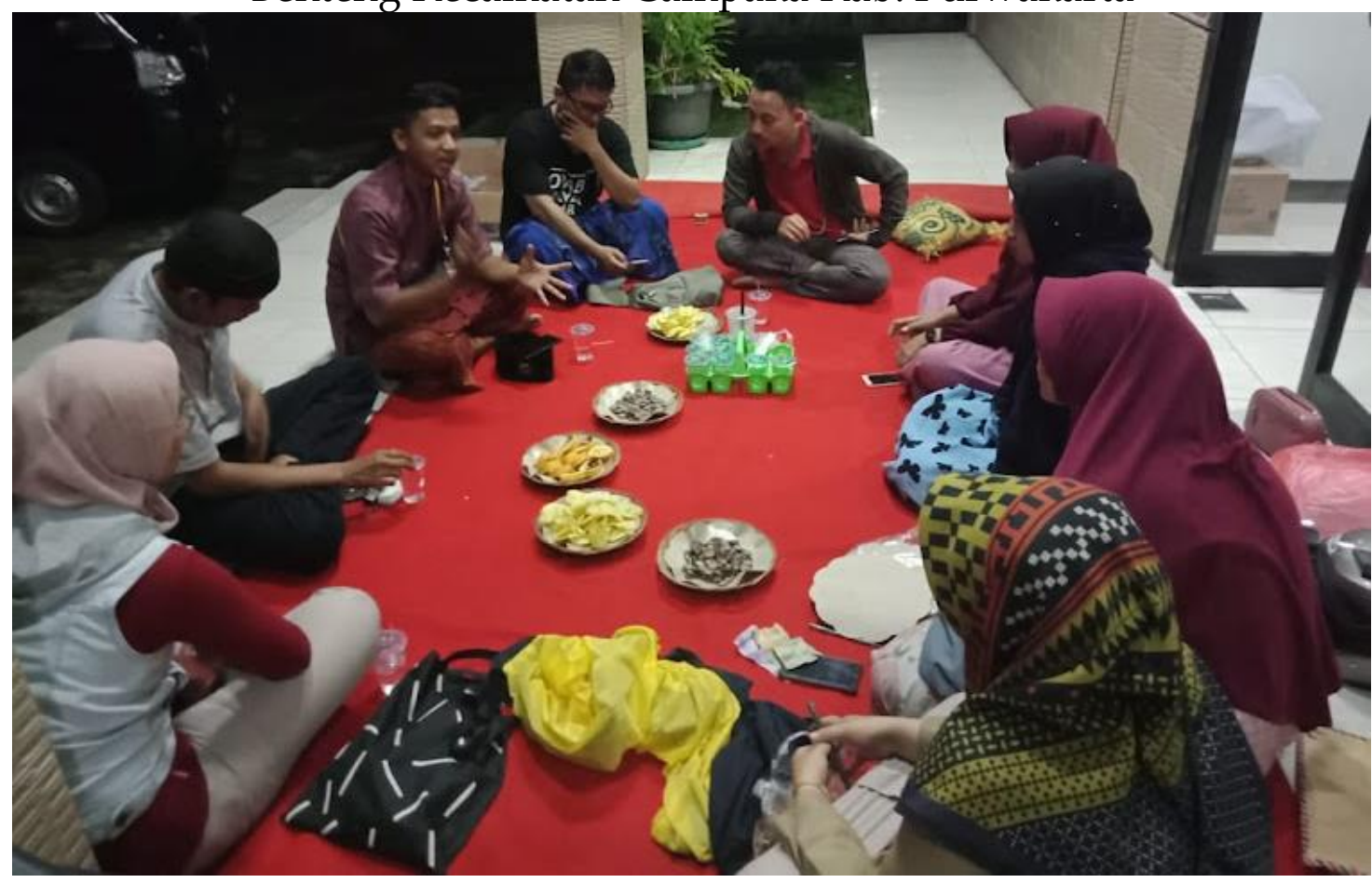

Pendataan dilakukan untuk memperoleh informasi penting berkaitan dengan pendaftaran dan pembuatan akun marketplace tokopurwakarta.com. Selain melakukan Sosialisasi marketplace tokopurwakarta.com kepada para pelaku UMKM, tim PKM juga melakukan sosialisasi marketplace tokopurwakarta.com kepada warga desa Benteng. Kegiatan ini bertujuan untuk mengenalkan marketplace produk asli orang purwakarta dan untuk meningkatkan jumlah pengguna marketplace tokopurwakarta.com. Serta mengenalkan transaksi kekinian (online) kepada masyarakat desa Benteng Kec. Campaka Kab. Purwakarta. Marketplace tokopurwakarta.com ini berguna untuk mempromosikan produk UMKM dan masyarakat desa Benteng Kec. Campaka. Electronic Commerce (e-commerce) merupakan konsep baru yang biasa digambarkan sebagai proses jual beli barang atau jasa pada 
World Wide Web Internet ${ }^{1}$. E-commerce dalam perspektif proses bisnis merupakan aplikasi teknologi menuju otomatisasi transaksi dan aliran kerja perusahaan ${ }^{2}$. Sedangkan dalam perspektif online, e-commerce berkaitan dengan kapasitas jual beli produk dan informasi di internet dan jasa online lainnya ${ }^{3}$.

E-commerce sangat memungkinkan penjual untuk memasarkan produknya secara cepat, mudah dan gratis ${ }^{4}$. Dengan mengupload foto dan mendeskripsikan produk yang didukung dengan recent update iklan yang muncul, tersedianya contact link dan tersedianya kontrol kualitas terhadap iklan penawaran barang dan jasa, iklan gratis bagi para pengguna dan cakupan wilayah iklan di seluruh Indonesia serta masih banyak yang lainnya.

\section{Gambar 3.2}

Sosialisasi Penggunaan Marketplace Tokopurwakarta.Com kepada UMKM dan Masyarakat di desa Benteng Kecamatan Campaka Kab. Purwakarta
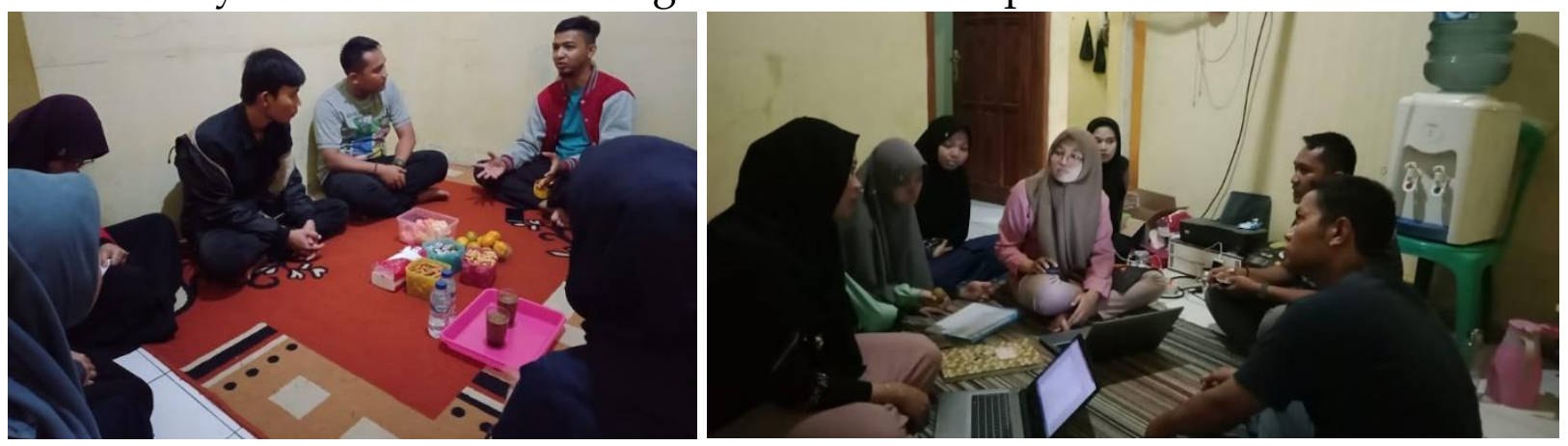

E-commerce mempunyai beberapa manfaat bagi konsumen, yaitu ${ }^{5}$ :

1. Memungkinkan pelanggan untuk berbelanja atau melakukan transaksi selama 24 jam;

2. Memberikan lebih banyak pilihan kepada pelanggan.

3. Pengiriman menjadi sangat cepat.

4. Pelanggan bisa menerima informasi yang relevan secara detail dalam hitungan detik, bukan lagi hari atau minggu.

1 Siti Maryama, "Penerapan E-Commerce Dalam Meningkatkan Daya Saing Usaha," Liquidity 2, no. 1 (2013): 73-79.

2 Apif Susanti and Dwi Wahyu Prabowo, "E-Commerce Pada Toko My Digital," Jurnal Penelitian Dosen FIKOM (UNDA) 4, no. 1 (2017).

3 Donni Prabowo, "Website E-Commerce Menggunakan Model View Controller (MVC) Dengan Framework Codeigniter Studi Kasus: Toko Miniatur," Data Manajemen dan Teknologi Informasi (DASI) 16, no. 1 (2015): 23.

${ }^{4}$ Rose Rahmidani, "Penggunaan E-Commerce Dalam Bisnis Sebagai Sumber Keunggulan Bersaing Perusahaan," Pengguna. E-Commerce dalam bisnis sebagai sumber keunggulan bersaing Perusah., no. c (2015): 345352.

${ }^{5}$ Dewi Irmawati, “Pemanfaatan E-Commerce Dalam Dunia Bisnis,” Jurnal Ilmiah Orasi Bisnis--ISSN 2085, no. 1375 (2011): 161-171.

ADINDAMAS (Jurnal Pengabdian Kepada Masyarakat), Volume 1, Nomor 2, Januari 2022 http://journal.sties-purwakarta.ac.id/index.php/adindamas/ ISSN: 2798-2874 (Media Online) 2798-4702 (Media Cetak) 
5. Memberi tempat bagi para pelanggan lain di electronic community dan bertukar pikiran serta pengalaman.

6. Memudahkan persaingan yang ada pada akhirnya akan menghasilkan diskon secara substansial.

Melalui program kerja pengabdian kepada masyarakat berupa pembuatan dan tatacara penggunaan akun marketplace tokopurwakarta.com diharapkan terjadi perubahan yang bermanfaat bagi pelaku UMKM dan warga masyarakat di desa Benteng Kec. Campaka Kab. Purwakarta dalam mamasarkan produk dan bertransaksi secara online.

\section{KESIMPULAN}

Kegiatan Pengabdian kepada Masyarakat yang telah dilaksanakan ini dapat diambil kesimpulan bahwa proses sosialisasi penggunaan marketplace tokopurwakarta.com mulai dari awal hingga tahap akhir dibuktikan dengan bertambahnya kepercayaan para pelaku UMKM dalam memasarkan produk jualannya, dan bagi masyarakat menambah pengetahuan tentang transaksi secara online pada marketplace tokopurwakarta.com.

\section{DAFTAR PUSTAKA}

Irmawati, Dewi. "Pemanfaatan E-Commerce Dalam Dunia Bisnis." Jurnal Ilmiah Orasi Bisnis--ISSN 2085, no. 1375 (2011): 161-171.

Maryama, Siti. "Penerapan E-Commerce Dalam Meningkatkan Daya Saing Usaha." Liquidity 2, no. 1 (2013): 73-79.

Prabowo, Donni. “Website E-Commerce Menggunakan Model View Controller (MVC) Dengan Framework Codeigniter Studi Kasus: Toko Miniatur." Data Manajemen dan Teknologi Informasi (DASI) 16, no. 1 (2015): 23.

Rahmidani, Rose. "Penggunaan E-Commerce Dalam Bisnis Sebagai Sumber Keunggulan Bersaing Perusahaan." Pengguna. E-Commerce dalam bisnis sebagai sumber keunggulan bersaing Perusah., no. c (2015): 345-352.

Susanti, Apif, and Dwi Wahyu Prabowo. "E-Commerce Pada Toko My Digital." Jurnal Penelitian Dosen FIKOM (UNDA) 4, no. 1 (2017). 